and of course it would make no matter whether this sporocarp were formed in the connecting canal as in Mesocarpus, or whether it fills this and extends over into both the cells as in Staurospernum, or as in Plagiospermum is altogether formed in one of the cells; the essential feature being the differentiation into the carpospore and its investing covering the sporccarp.

Now Dr. Wittrock has made the rather startling observation that in one and the same species (Mougeotia calcarea, Clev.), the formation of the spores may take place equally in the manner of the three above-mentioned genera; also that occasionally even the spores may be formed without any conjugation, and further that in a plant found growing last October in an aquatic stone house in the Upsala Botanical Gardens, and which is described as Gonatonema ventricosum, the spores are formed in a neutral way through the agency of cells never intended for and incapable of conjugation. Such spores the autbor calls agamospores, and he finds a second species of this new genus in Hassall's anomalous Mesocarpus notabilis. This memoir of Wittrock's will be found in the Bikang till k. Svenska Vet. Akad. Handlingar, Band 5, No. 5, 1878. It is written in English, and illustrated with a plate. Upon it the following observations may not seem altogether out of place.

If the interpretation placed on the phenomena to be witnessed in the Mesocarpere by Prof. Pringsheim be accepted, then this family can scarcely be left among the Conjugatx, and this would hold true also of Wittrock's new genus, as indeed is so stated by himself. But may not the phenomena be interpreted in yet one other way? First, as to the agamospores in Gonatonema. Is it beyond the bounds of possibility that, despite their external likeness to zygospores, these are simply vegetative spores, to be compared to one of the so-called tetraspores in Florideæ? They surely cannot be compared to any form of organism itself the product of the commingling of the contents of two different cells! Another suggestion, to account for this agamospore, has been made to me by my friend William Archer. It is that there may have been a separation between the upper and lower portions of the protoplasmic contents of the same cell, and that these, without waiting for the formality of forming separate cells, may have then and there conjugated. This is certainly a most ingenious suggestion, and is strengthened by the well-known fact that, in some Desmids, after the single-celled frond has divided into two halves, and before the newer portions grow into anything like the similitude of the older portions, the two halves, which were only just parted, will conjugate and form an ordinary zygospore. De Bary gives some pretty figures of this strange phenomenon, which, according to Mr. Archer, might be carried one step further, and there be no parting at all. In favour of my own idea I can only add that the first origin of what, in some of the Floridex, will form the tetraspores, and the origin of these agamospores, appear to me to be the same. Next as to the sporocarps in Mesocarpus. The differentiation into sexual entities of the protoplasinic contents of cells is confessedly, at first, scarcely perceptible. It would be impossible, in many cases, to say with any confidence, this one is the germ cell, and that one is the sperm cell. But gradually a differentiation appears in that the contents of the former exhibit themselves as passive, and of the latter as active; the contents of the one remain quiescent, those of the other pass over to conjugate with the former, but all through the contents that commingle are almost in every case alike in quantity. Carry the differentiation a step further on, and we find that the contents that comningle may be at first somewhat, and then be strikingly unlike in quantity. The passive contents will be divided into a comparatively small number of portions (in Fucus eight), but these each can be fertilised by the very smallest portion of the active contents. Now may not the Meso- carpeæ be a link between these groups? The contents of each of the two cells divides into certain portions. The fertilising power of the active contents is not sufficient for the passive contents, and hence but one portion-that the most specialised-is fertilised ; this forms the zygospore; the other portions remain sterile. Then this spore would differ from the zygospore of Zygnema just in the same proportion as it would differ from the oospore of Fucus, but the fructification would not at all be a representative carpospore, and the at first sight very anomalous case of $M$. calcarea may be explained by supposing that the number of partitions is a matter of but secondary importance, unless the fertilising power of the active contents were to increase. This field of research is an important one, and much as we are indebted for information on these points to the labours of the Swedish botanists, we must still continue to look for fresh facts and new explanations.

\section{E. PERCEVAL WRIght}

\section{PROF. C. F. HARTT 1}

CHARLES FREDERIC HARTT, whose death by yellow fever occurred at Rio de Janeiro on the 18 th of last March, was born at Fredericton, New Brunswick, August 23, 1840. For three years and a half before his decease he had successfully withstood the fatigues of exploration and the labours of organising and carrying on the geological commission of Brazil, an undertaking beset with many trying difficulties.

Prof. Hartt's connection with natural history dates from boyhood. Encouraged by Prof. Cheesman, he made rapid progress in his favourite studies, without, however, neglecting the other branches of learning. But his particular bent always lay toward natural history, language, music, and art.

While a student at Acadia College, he undertook, under the direction of Dr. Dawson, extensive researches into the geology of Nova Scotia, which province he explored on foot from one end to the other. In i 860 he accompanied his father to St. John, there to establish a college high-school. This change of location brought him into another field for exploration, that of the geology of New Brunswick, and he commenced his new labours at once. The Devonian shales at the locality called Fern Ledges, in the vicinity of St. John; were the principal objects of his research. After a long siege of hard work he was amply repaid by discovering an abundance of land plants and insects, of which the latter still remain the oldest known to science. Prof. Agassiz was attracted by this last discovery of the young Canadian naturalist, and invited him to enter his museum at Cambridge as a student. This he did in $186 \mathrm{I}$. Each vacation he returned, either to New Brunswick or Nova Scotia, to continue his explorations. In $1864 \mathrm{Mr}$. Harti was employed, with Profs. Bailey and Matthews, on the geological survey of New Brunswick, and, while engaged in this work, obtained the first full proof of the existence of primordial strata in that province. Many of his discoveries in Nova Scotia and New Brunswick were published in the Provincial Government reports, and also in Dr. Dawson's "Acadian Geology."

Upon the organisation of the Thayer Expedition to Brazil, by Prof. Agassiz in 1865, he was appointed one of its geologists, and henceforth to the time of his death. he was ever a most devoted investigator of South American natural history. Aided by New York friends he returned to Brazil alone in 1867 , this time examining with the greatest care the reefs of the Abrolhos Islands, and those of the coast, as well as the geolosy of a part of Bahia and Sergipe. The results of his work thus far were pub$I$
June. 
lished in I 870 as the "Geology and Physical Geography of Brazil." In addition to the account of Hartt's researches, it included the best results of all who had ever published on the geology of the country.

Early in 1868 he was elected Professor of Natural History in Vassar College, and shortly after of Geology in Cornell University. In 1870 , with Prof. Prentice and eleven students of Cornell University, he again went to Brazil. He entered the Amazonian Valley, hoping there to discover, at the falls of the different tributaries of the Amazonas, other fossiliferous formations than the cretaceous, which latter alone he bad found along the coast. He was well rewarded, and returned to the United States with large collections of fossils of the palæozoic age, and sufficient other evidence to allow of his giving us a very accurate though general idea of the formation of the Amazonian Valley. His results were strongly opposed to the theory of Prof. Agassiz, of its glacial origin. He returned again to the Amazonas in $187 \mathrm{I}$ with Mr. O. A. Derby. Together they carefully reexplored the same regions gone over before, adding mush to the stores already brought to the United States, and also examining the ancient Indian mounds and shell-heaps of numerous localities.

Returning from Brazil once more he remained at Cornell University about three years, quietly working up the results of his later trips, and publishing his reports upon them. In August of 1874 , by request of the Brazilian Minister of Agriculture, he went to Rio de Janeiro to submit his plans for the organisation of a Geological Commission of Brazil. He entered on his work in May, 1875 , with five or six assistants.

On the reorganisation of the National Museum at Rio, in 1876 , Hartt became Director of its Department of Geology, but on account of his many other duties he was soon obliged to resign that position. The results of his researches may be briefly summed up as follows:-Before he went to Brazil on his second trip, in 1867, scarcely anything was known of fossiliferous deposits there, and thus no material existed toward the study of the systematic geology of the country. A few cretaceous fossils had been recorded from Bahia; the Danish naturalist Lund had very fully described the bonecaverns of Lagoa Santa in Minas Gerães, and we knew of coal-plants from Rio Grande do Sul, but beyond this the palæontology of Brazil was a perfect blank. Hartt's greatest achievement in Brazil was probably his solution of the structure of the Amazonian Valley. It was founded on the best of palæontological evidence which proves the existence of an immense palæozoic basin lying between the metamorphic plateau of Guiana on the north, and that of Central Brazil on the south, and through which flows the river Amazonas. Silurian, Devonian, and carboniferous rocks, make up the series in regular succession, and in many localities are higbly fossiliferous. $\mathrm{He}$ has explained the character of the isolated cretaceous deposits, mostly discorered by himself, existing along the coast from Para to Bahia, and of the carboniferous and other regions south of Rio. He has shown us the manner in which the rocky structure of Brazil was built up, and has done much toward solving the relations of the crystalline rocks which compose by far the larger portion of its surface. He has explored the shell-heaps, burial-mounds, and other relic-localities of the prehistoric tribes from far up the Amazonas to the southernmost coast province. We owe to him aiso the first real satisfactory explanation of the reefs of Brazil, which he distinctly shows to be of two kinds-sandstone and coral. He spent much time in studying the customs and languages of the modern Indian tribes of the Amazonas and Bahia, and collected very much material toward a grammar and dictionary of the Tupé Indian language in several of its dialects. But to attempt a complete
account of Prof. Hartt's Brazilian explorations and dis- coveries would require a longer article than we can gire here. In connection with the Geological Commission of Brazil be founded a large museum in Rio de Janeiro, which will always bear testimony to his great final undertaking. It forms the most complete repository of South American geology in the world.

A start had just been made toward publishing the reports of the commission when the death of Prof. Hartt deprived it of its main support. But though this will occasion some delay in the publication, it is to be hoped that we shall soon have before us the entire results of this most important of explorations.

Prof. Hartt's published works are not very voluminous. He was so confident of a longer life that he delayed too long, but still he was a constant contributor to American scientific periodicals.

\section{THE DAKK CONTINENT'}

I N our article last week on "Old Maps of Africa" we said that even if it were the case that the great lakes and rivers of Central Africa were known to early Portuguese missionaries and traders, it would not in the least detract from the glory of modern African explorers. Even if the work of those early travellers had not been clean forgotten, it was done so imperfectly that in any case it would have had to be done over again; their work bears about the same relation to that of modern explorers that the observations of an ancient Chaldean shepherd watching with powerless eyes the march of the stars, while he tended his flock on the hill-side, do to those of a modern astronomer armed with all the instruments of an observatory. It scarcely needs a perusal of these two volumes to convince us that it would be simply absurd to attempt to deprive Mr. Stanley of the glory of being the first white man whose keel has cleaved the broad bosom of the Upper Congo. He has done his work in such a way that there is no chance of it being ever forgotten.

Let us at once assure those of our readers who may cherish the idea that, after having read Mr. Stanley's letters in the Telegraph, they need not trouble themselves with his book, that they labour under a delusion; compared with the book, the letters are a mere prospectus, and therefore we cannot hope within the limits of an article to give any adequate idea of its contents. From a merely literary stand-point, Mr. Stanley's work deserves to take a high rank. We know no other narrative of travel with which it can be compared; it reads more like a prose epic than a story of stern facts, and the reader who remembers his classics will be over and over again reminded of the story of the wanderings of UIysses as chanted by Homer. No such revelation of African life and African character and African scenery has ever been made, scarcely, we think, even in the half-fictitious pages of Winwood Reade. The trustworthiness of Mr. Stanley's narrative cannot for a moment be doubted; his art has been evidently used simply to enable us to realise with perfect clearness the scenes and events through which he and his followers passed.

From the numerous notices we have published, our readers must be familiar with the great outlines of $\mathrm{Mr}$. Stanley's discoveries. The two volumes before us are concerned mainly with the incidents of the wanderings of himself and followers from Bagamoyo to the mouth of the Congo; another volume, which is promised for autumn, will contain chapters on the hydrography, ethnology, and natural history of Central Africa, with "considerations" on the lakes, lands, and peoples of the equatorial regions; as well as chapters on the hydrography and physical geography of the western half of

i " Through the Dark Continent, or the Sources of the Nile, around the Great Lakes of Equatorial Africa, and down the Livingstone River to the Atlantic Ccean." By Henry M. Stanley. Two vols. Maps ard Illustraticns. (Lordon: Sampson Low and Co., 1878 ) 